\title{
Magyarország és a globális közlekedési tér
}

\section{Hungary and the global transportation area}

\section{ERDŐSI FERENC}

ERDŐSI Ferenc: kutató professzor emeritus, MTA Közgazdaság- és Regionális Tudományi Kutatóközpont, Regionális Kutatások Intézete; 7621 Pécs, Papnövelde u. 22.; erdosi@rkk.hu; https://orcid.org/0000-0002-9793-8112

KULCSSZAVAK: globális közlekedési tér; tengerhajózás; kikötőelérhetőség; Magyarország; Budapest; légi közlekedés

ABSZTRAKT: A nyitott gazdaságú országok számára fontos, hogy mennyire képesek integrálódni a világgazdaságba és az azt kiszolgáló globális közlekedési rendszerbe. A távoli kontinensekkel folytatott kereskedelemből (a megfelelő peremfeltételek mellett) a komparatív előnyök kihasználása révén extra haszon származhat. Magyarország gazdasága már a 20. században is igen erősen az európai exportra orientált volt. Az utóbbi évtizedekben végbement szerkezetváltás növelte a távoli (főként kelet-ázsiai) beszerzési piacok jelentőségét. Ezért a magyar gazdaság működése szempontjából sem közömbös, hogy mennyire képes bekapcsolódni a globális áruszállítás rendszerébe, melynek meghatározó eszköze (Oroszország nagy része és Közép-Ázsia kivételével) csak a tengerhajózás lehet.

A különféle opciókat vizsgálva a szerző áttekintést ad a hátrányos tenger nélküli helyzet enyhítését szolgáló korábbi magyar Duna-tengerhajózásról és „mélytengeri” hajózásról, megszünésük okairól és következményeiről, továbbá a korunkbeli (szállítástechnológiai korszakváltás által is befolyásolt) kikötőválasztás lehetőségeiről. A tanulmány bemutatja a hazai tengerhajózás szükségességéről, a nemzeti flottához való ragaszkodásról vallott különböző nézeteket. Miért és hogyan ütköztek egymással az ágazati (a hajózási szakembergárda és a - kisebb tengeri hajók fogadására alkalmas - csepeli kikötő által képviselt) parciális érdekek a nemzetgazdaságinak minősített érdekkel a fennmaradás versus megszüntetés dilemmájában? A korábbi megszüntetést kényszer szülte „kváziracionális" opciónak értékeli a szerző, mivel a konténerhajók vásárlásához szükséges tőke hiánya volt a meghatározó tényező a döntéskor. A mai gazdaságossági számítások tükrében már több érv szól a külföldi hajózási társaságokkal való szállíttatás mellett.

Kedvezőbb helyzetben van Magyarország a globális légi közlekedési tér eléréséhez. A nemzeti légitársaság (MALÉV) megszűnése ellenére Budapestről közvetlen távolsági járatokkal több desztináció érhető el, mint a környező nyugat- és kelet-balkáni országok fövárosaiból. Viszont a regionális hub szerepét továbbra is Bécs (és részben Prága) tölti be.

A jövőben az Isztria-közeli kikötők szerepe Magyarország külkereskedelme számára erősödik, viszont a direkt globális légi vonalak száma számottevően nem növekszik.

Ferenc ERDŐSI: research professor emeritus, Institute for Regional Studies, Centre for Economic and Regional Studies, Hungarian Academy of Sciences; Papnövelde u. 22., H-7621 Pécs, Hungary; erdosi@rkk.hu; https://orcid.org/0000-0002-9793-8112

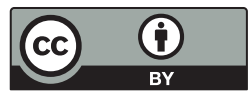


KEYWORDS: global transportation area; maritime shipping; port accessibility; Hungary; Budapest; air transport

ABSTRACT: For the Hungarian economy, the extent in which it can be involved in the global sea shipping system is important. Trade with distant continents (within the appropriate conditions) can generate profit thanks to comparative advantages. Hungary's economy was already highly oriented towards European exports even in the 20th century. The restructuring of the last decades, furthermore, increased the importance of distant (mainly East Asian) procurement markets. Therefore, considering that maritime shipping (except for most of Russia and Central Asia) may be the only means of transport to these place, the extent in which it can integrate into the global freight system can be a key factor.

Looking at the various options, the author gives an overview of the former history of Danube maritime shipping and deep-sea shipping, the causes and consequences of their disappearance, and the contemporary novel options for selecting a harbor (emerged thanks to transport technology innovations).

The article also presents opinions about the necessity of domestic shipping and of a national fleet. It describes how and why the dilemma around survival versus elimination represented the collision of the interests of shipping professional and the port of Csepel (to accommodate smaller maritime vessels) with the alleged interests of the national economy.

The author considers the earlier termination as a "quasi-rational" option because the primary factor in decision-making was the lack of capital needed to purchase container ships. In light of contemporary economic calculations, however, now there are several arguments for shipping with foreign companies.

Hungary, nevertheless, is in a better position to reach a global aviation space. In spite of the disappearance of the national airline (MALÉV), Budapest has several direct routes to the main cities of neighboring Western and Eastern Balkan countries. However, the role of the regional hub remains in Vienna (and partly in Prague).

In the future, the nearby ports of Istria will increase Hungary's foreign trade, but the number of direct global air routes will not increase significantly.

In Hungarian foreign trade and tourism, the weight of global relations is growing, but its share from goods and passenger transport and logistics (with the highest competition) will only be modest (through complementary and traffic management activities).

\section{Bevezetés}

Elméletileg globális közlekedési tér alatt a glóbusz történelmi korszakonként változó kiterjedésű és szerkezetű közlekedési hálózata által lefedett, elérhető területét és légterét értjük, melyen belül különböző forgalmi intenzitású útvonalakon történik a kontinensek közötti és kontinenseken belüli (világ)kereskedelem, valamint személyforgalom (Erdősi 2010a). Lényegében a szakirodalomban gyakran használt közlekedési tér („egységes európai közlekedési tér” - European Commission 2001) legmagasabb fokozatáról van szó. E terminus technicus azonban az ismert angol és német szakirodalomban ritkán bukkan fel.

Képletesen akár háromlábú székhez is hasonlítható a globális gazdaság szerkezete (Erdősi 2005c). Három „lába”, azaz erőközpontja (Európa, ÉszakAmerika, Kelet-Ázsia) között áramlik (egyre erősebb irányokbeli különbségekkel) a tengeri kereskedelemben részt vevő áruk (értékben) mintegy 85\%-a. E 
„fösodor” az északi félteke kontinensei között abroncsszerü alakzatot öltve magába foglalja a három (Csendes-, Indiai- és Atlanti-) óceánt, valamint a Vöröstengert és a Földközi-tengert hosszában átszelő hajózási világútvonalat a közbeiktatódó Szuezi- és a Panama-csatornával együtt. (A tisztán tengeri fóútvonalhoz kapcsolódva alárendelt jelentőségű, 1-3\%-nyi a transzeurázsiai és az Észak-Amerikát átszelő szárazföldi korridorokkal kiegészülő kombinált globális szállítási rendszer - Erdősi 2010b.) A globális légi közlekedés térszerkezetére az erőközpontok közötti forgalom szuperintenzitása ugyancsak jellemző, ám a légtér ma már politikai okok miatt alig korlátozott használatából adódóan a tengerhajózáshoz képest jóval több vonalváltozaton közlekednek az interkontinentális légi járatok (Erdősi 2010a).

Cikkünkben egyrészt azt szeretnénk bemutatni, hogy a mai Magyarország számára milyen lehetöségek léteznek a globális tengeri árukereskedelembe való bekapcsolódáshoz (melynek fontosságát már Kossuth is kénytelen volt hangsúlyozni - „Tengerre magyar”! - Erdősi 2005b), másrészt rövid elemzést adunk „a tengerentúli” világrészekkel létező légi (személy)közlekedési kapcsolatokról.

\section{A globális áruszállításba való bekapcsolódás problémái}

\section{A tengerentúli világ súlya külkereskedelmünkben}

Magyarország külkereskedelmének és állampolgárai külföldi utazásainak túlnyomó része hagyományosan intraeurópai. (Még az 1945-1989 közötti időszakot sem tekinthetjük kivételnek, mert a nagy arányban a Szovjetunió felé orientálódott export a birodalom európai régióiban hasznosult, ahogyan az importáruk többsége is az Uráltól nyugatra levő országrészből származott.) Mindemellett érdemes számba venni, hogy az Európán kívüli (azaz praktikusan a globális) világgal folytatott tengeri kereskedelem milyen méreteket öltött a különböző viszonylatokban.

A külkereskedelem kontinensek szerinti megoszlásának időbeli változása (értékalapon) a Magyar Statisztikai Évkönyv évfolyamaiból követhető nyomon (1. táblázat). Európa súlya a magyar külkereskedelemben évtizedek óta nagyjából változatlan; a rendszerváltás után kissé erősödött, viszont az utóbbi időkben közelebb áll az 1980. évihez, mint az 1995. évihez. Miközben Európa részaránya állandónak bizonyult, a globális külkereskedelem földrajzi megoszlásában jelentős eltolódások mentek végbe. Az importból csaknem megkétszereződött Ázsia részaránya (kínai áruinvázió!), Amerikáé viszont megfeleződött (többek között a brazíliai szója és az észak-amerikai műszaki berendezések, gyártmányok visszafogottsága okán), Afrika pedig marginalizálódott. A kivitelből az ázsiai és afrikai piac részaránya még mindig nem érte el az 1980. évi szintet 
1. táblázat: Magyarország külkereskedelmének megoszlása világrészek szerint, 1980-2015 (Ft-érték alapján)

The distribution of Hungary's foreign trade by continents between 1980-2015 (in HUF)

\begin{tabular}{lcccccc}
\hline \multirow{2}{*}{ Világrészek } & \multicolumn{2}{c}{1980} & \multicolumn{2}{c}{1995} & \multicolumn{2}{c}{2015} \\
\cline { 2 - 6 } & Behozatal, \% & Kivitel, \% & Behozatal, \% & Kivitel, \% & Behozatal, \% & Kivitel, \% \\
\hline Európa & 84,7 & 86,7 & 87,4 & 88,2 & 84,3 & 87,7 \\
Ázsia & 6,6 & 7,3 & 6,7 & 4,5 & 12,9 & 5,7 \\
Afrika & 1,6 & 3,3 & 1,0 & 1,0 & 0,1 & 1,1 \\
Amerika & 6,5 & 2,6 & 4,9 & 3,9 & 2,7 & 5,0 \\
Ausztrália és Óceánia & 0,5 & 0,1 & 0,0 & 0,2 & 0,0 & 0,5 \\
\hline Összesen & 100,0 & 100,0 & 100,0 & 100,0 & 100,0 & 100,0 \\
\hline
\end{tabular}

Forrás: Magyar Statisztikai Évkönyv 1980, 1995 és 2015. évfolyamai.

(amikor ipari berendezéseket, járműveket nagy számban szállított Magyarország a műszakilag elmaradott országokba), viszont az amerikai értékesítési piac pozíciója tartósan erősödő irányzatú (1. táblázat).

Értékalapon tehát a teljes magyar külkereskedelem 14\%-a jut a többi világrészre (beleértve az ázsiai FÁK-államokat is). Ebből a 14\%-ból a közúti és vasúti szállítás becslésünk szerint legfeljebb 3-5\%-kal részesedik. (Szibériából az olaj és a gáz csővezetéken érkezik.) Mindezeket figyelembe véve a „tengerentúli világrészekre" értékben a teljes magyar tengeri külkereskedelemnek maximum a 9-11\%-a jut.

Ezek az adatok azonban a szállítási feladatok számszerü értékeléséhez használhatatlanok, mivel e szempontból a szállítmányok tömege (súlya) és részben egyedi mérete a meghatározó. A gazdasági szerkezet- és szállítási technológiaváltás nyomán a külkereskedelem árutömege az utóbbi 30-40 évben nem csupán az Európán belüli viszonylatokban lett lényegesen kisebb (hogy csak az egykori tekintélyes ukrajnai, illetve lengyelországi vasérc-, feketeszénés kokszimport töredékére csökkenésére, a timföld- és egyes vegyipari alapanyag-kivitelünk megszűnésére utaljunk), hanem globálisan is. Az Európán kívüli külkereskedelem áruszerkezete ma lényegesen különbözik a korábbiaktól, alig vannak jelen az importban a nagy súlyú ömlesztett áruk, ahogyan exportunkból is hiányoznak, viszont jóval több lett mindkét irányban a (magasabb fajlagos értékü) general cargo (azaz gépkocsik, gépi berendezések) és még inkább a konténerizált áru (a ruházati cikkektől az értékesebb műanyagokon és háztartási, illetve audiovizuális készülékeken, számítógépeken, autóalkatrészeken keresztül a gyógyszerekig). Azonban az értékaránytól még mindig eltérőek lehetnek a magyar globális külkereskedelem tonnasúlyarányai, melyekkel a közlekedési módoknak számolniuk kell.

Az Európán belüli (kiváltképpen a kelet-közép-, közép- és nyugat-európai) országokkal folytatott árucserében meghatározó a vasúti és a közúti közlekedés (még a személyközlekedés tekintélyes része is szárazföldön áramlik). Ezzel 
szemben a többi világrésszel folytatott árucsere szinte kizárólag a tengerhajózásra kénytelen hagyatkozni. A hazai gazdasági igényekkel többé-kevésbé harmonizáló mindenkori külgazdaság-politika erősen befolyásolja, hogy az Európán kívüli világrészeknek milyen a súlya a külkereskedelmen belül. Az utóbbi időben a kormány meghirdette a keleti nyitást, majd a dél felé fordulást, ezzel felértékelődtek az ázsiai (különösen a kelet-ázsiai) és szorosabbá válhatnak az afrikai kapcsolatok.

Becslések szerint a tengerhajózásra századunk elején évi átlagban mintegy 120-140 ezer TEU konténeres áru és a mintegy 250-300 ezer tonna nem konténerizált export- és importáru egytizedének szállítása várt. A tengeren behozott áruk bő háromnegyede Kelet-Ázsiából, gyenge egytizede Amerikából származott, míg a más kontinensekre kivitt áruk közel 2/6-át Amerikában, 3/6-át Kelet- és Dél-Ázsiában, 1/6-át a Közel-Keleten és Afrikában rakják ki János 2008). Azóta a konténerizált áruk kerültek túlsúlyba főként a kínai forgalom felfutása következtében.

\section{Törekvések a tengerhajózásra}

Modern kori gazdaságtörténetünk során az Európán kívüli világ súlya Magyarország külgazdasági kapcsolati rendszerében a tengeri kapu szerepet betölto” kikötők elérhetőségétől függően is változott.

A Monarchia keretei között Fiume előnyben részesítése mellett a tengeri kereskedelem jelentős része (a távoli világrészekkel való kereskedéshez több járatváltozatot kínáló) Trieszten keresztül áramlott. (A 20. század elején az Európán belüli áruszállítást is nagyobb arányban szolgálta a magyar tengerhajózás - pl. a Nyugat-Európába és Olaszország déli tartományaiba történt gabona- és fakivitellel.) A korabeli forgalmi statisztikákból (Fiume hajó- és áruforgalma... 1915) tudhatóan az osztrák és a magyar kikötőből néhány menetrendszerü teherhajójárat Dél-Ázsiát érintve Kelet-Ázsiába is közlekedett. A két világháború közötti, tengerpart nélküli maradék Magyarország jóval kisebb méretü külkereskedelmében a tengerentúli viszonylatok már szerény részaránnyal szerepeltek (Erdősi 2000).

Az 1948 utáni évtizedekben ugyan a szovjet tömbhöz, a KGST-hez tartozás nyomta rá a bélyegét a külgazdaságra, azonban a szocializmussal kacérkodó harmadik világbeli (ázsiai és afrikai) országok segítése is megmutatkozott a külkereskedelemben. Miután a szocialista tervgazdaság nem volt igazán szállításiköltség-érzékeny, alacsony fajlagos értéku” „kapcsolt” áruk - pl. szíriai cement, egyiptomi sör - is megjelentek az állami üzletekben (a szerző egykori személyes tapasztalatai).

Ugyan a távoli világrészekkel folytatott kereskedelem nagyobb részét külföldi hajózási társaságok igénybevételével oldottuk meg, az akkori kormányzat igyekezett az export- és importáruk minél nagyobb részét magyar állami tulaj- 
donban levő hajókkal szállítani. Magyarország már az 1930-as évektől úttörője volt a Duna-tengerjáró hajók gyártásának, valamint e különleges (kettős funkciójú) vízi járművekkel a Csepeli Szabadkikötő és a Fekete-tenger/Mediterráneum között folytatott közvetlen szállításoknak. E hagyományt folytatva került sor folyam-tengerjáró flottánk nagyszabású fejlesztésére és múködési területének kiterjesztésére a Közel-Keleten és Észak-Afrikában (Magyar tengerhajózás 1945 után é.n.). Az 1100-1300 tonnás hajók számára a közlekedést megkönnyítették az al-dunai szakaszon az 1970-1980-as években épült román-jugoszláv vízi erőművek gátjai, melyeknek még Újvidéknél is érezhető volt a visszaduzzasztó hatása. A vízállás szabályozásával biztonságossá vált a hajózás a vaskapui szakaszon. (E „Duna-szauruszok” kedvezőtlen környezeti hatásaitól természetesen nem tekinthetünk el - Erdősi 2008a.) Az al-dunai duzzasztás ellenére a folyam magyarországi szakaszán egyes években az alacsony vízállás miatt hónapokig szünetelt e szállítási mód, mely egyébként a Duna-torkolati átrakást feleslegessé téve kitűnt a hatékonyságával.

Néhány „mélytengeri” fuvarokra (Bulgáriában és Lengyelországban) épült MAHART tengeri hajó a távoli világrészeken beszerzett, illetve oda küldött áruk „saját rezsiben” történt szállítására adott lehetőséget. Mindezekre figyelemmel Mizik (1995) úgy látta, hogy a rendszerváltás előtti évtizedekben a magyar tengerhajózás fontos gazdasági „küldetésének” tett eleget:

- a Dunán, a recipiens, valamint más tengereken és részben a világóceánon közlekedve ellátta a tengeri export-import szállításaink 18-20\%-át;

- kiterjedt nemzetközi kapcsolatrendszere révén a politikai elzárkózás kényszerü évtizedeiben állandó összekötő kapocs, továbbá fontos devizatermelő és devizakímélő szerepet is betöltött.

\section{Szállítási/logisztikai technológiaváltás vagy önkényes kormányzati döntés? (A magyar Duna-tengerhajózás megszüntetésének okai)}

A Duna-tengerhajózás lassú leépülése már az 1970-1980-as évek fordulóján megkezdődött, és a rendszerváltás idejére lényegében befejeződött. Csak mutatóban maradt pár hajó magyar lobogó alatt az 1990-es években, a többit megvették európai és kelet-ázsiai társaságok (Fáy 1995).

Szakmai körökben máig nem tisztázott teljesen, hogy e nemzeti szemszögből akár drámainak is érzékelhető folyamat a szállítási technológiaváltás kényszeréből adódó szükségszerű változtatás, avagy elsietett, kellőképpen nem átgondolt kormányzati döntés következménye volt-e. (A felszámolás késői szakaszában a korrupció lehetősége is felmerült - a hajók eladásából származó bevételek sorsának homályosságából adódóan.)

A fó okot minden bizonnyal az innovatív megoldás átvételével való sikertelen próbálkozásban kell keresni. Az 1980-as években a vízi szállításban már elterjedt az arra alkalmas különféle darabárukat könnyen mozgatható nagy 
konténerekben elhelyező technológia, ami lényegesen lerövidítette a rakodás idejét és csökkentette költségét. További (ugyancsak költségcsökkentéssel járó) előnye, hogy a konténeres szállítmány indítópontja és célállomása (desztinációja) közötti forgalomban részt vevő aktorok száma lecsökken, mert kiiktatódnak a szállítmányozók (két jogi személy): a külkereskedő közvetlen partnerévé a tengerhajózási társaság vált, nincs szükség már olyan közvetítőkre, akik átveszik a konténerizált áruszállítási lánc megszervezésének szerteágazó feladatát (Stopford 2013).

Magyarország a Dunának köszönhetően bekapcsolódhatott a négy szocialista ország által már 1976-ban alapított INTERLIGHTER társaság szervezésében működtetett folyami-tengeri bárkahordozó kombinált áruszállításba. A Dunán darabáru-szállítmányt, majd konténereket gyüjtő és szétosztó bárkákat a torkolatnál nagy befogadóképességü (szovjet) anyahajók vették fel, majd ezekkel megrakodva eljutottak Hátsó-Indiába, ahol a Mekong és az Irrawaddy torkolatában folyóvízre bocsátották a bárkákat. Kirakodás után a folyami kikötőkben importáruval megrakott bárkákat az anyahajó visszahozta a Dunára, hogy a szállítási ciklus újrakezdődjön. A vietnami, kambodzsai és mianmari háború azonban megpecsételte ennek a hatékony interkontinentális szolgáltatásnak a sorsát (Erdősi 2007a).

Ilyen előzmények után Magyarország az 1980-as évek elején elsőként használta a dunai vízi utat tengerentúli viszonylatokban konténerek fuvarozásához. Paradox módon e progresszív lépést az eladósodott ország végletekig erőltetett exportja kényszerítette ki. (A Közel-Keletre konténerekben juttatták el a feldolgozott mezőgazdasági termékeket.) A szovjet SDP hajózási társaság közreműködésével a magyar kikötőkből 600-800 tonnás bárkákkal 300-400 TEU konténert vitettek le Izmailba, ahol azokat átemelték tengeri hajókra. Ez a megoldás akkor a társaság alacsony tarifái miatt gazdaságosabbnak bizonyult, mint az adriai kikötőkön keresztül folytatott szárazfölditengeri szállítás (Erdősi 2008a).

Magyarország azonban gyakorlatilag nem csupán a Fekete-tenger, hanem az Ausztria és Németország felé irányuló hagyományos nemzetközi folyamhajózást is alacsony szintre csökkentette. (Érvként időnként még azt is felhozták, hogy a klímaváltozás miatt egyre hosszabb a hajók teljes kapacitással történő közlekedését a kisalföldi zátonyos Duna-szakaszon lehetetlenné tevő alacsony vízállás. A bősi erőmű megépítése óta az alvízi szakaszról szólnak a kritikák.)

\section{A konténerszállitás gazdaságtalansága a Duna-Majna(-Rajna)-csatornán}

Magyarországon is nagy várakozás előzte meg a Duna-Majna-Rajna-csatorna megépítését. A belvízi hajózás szakemberei abban reménykedtek, hogy az új vízi úton fuvarozzák a konténereket Rotterdamba, azonban erre alig került sor, mert hiányoztak a kiegészítő feltételek. 
Az 1992-ben megnyitott mesterséges németországi vízi út korántsem felelt meg a (hazánkban is) hozzá füződő reményeknek (BR online 2008). Nem a medrével és rengeteg szűk zsilipjével van igazán baj. Az összesen közel félszáz zsilip ugyan a hajózás időigényét (14 napra) és ezzel a költségeit is növeli - ezzel eleve számolnia kellett a magyar belvízi fuvarozóknak, illetve a szállíttatónak -, hanem a vízi úton való hajózás müszaki korlátjaival. Ömlesztett áruk és a fedélzet fölé csak bizonyos magasságig emelkedő általános áruk (pl. jármüvek) szállításának nincs különösebb akadálya a maximum 1350 tonnás szabványméretü („Európa”) hajókkal.

Amikor a csatornát tervezték (az 1960-as évek végén) a konténerszállítás még marginális feladatnak tűnt. Azonban az időközben végbement struktúraváltás következtében az 1990-es évekre kiderült, hogy éppen a konténerszállítás iránt van igazán igény, ha árban versenyképes a szárazföldi szállítással. Ahhoz, hogy a rentabilitás követelményének a szállító megfeleljen, a konténereket a belvízi hajókon egymás fölött három sorban kell felhalmozni. Így az egy konténerre jutó szállítás költségét meghaladhatja a szolgáltatás ára. Azonban a hidak alacsony pályája csak maximum 2 szinten teszi lehetővé a konténerek elhelyezését. Ezért csak abban az esetben érdemes a magasabb fuvardíjat megfizetni, ha kifejezetten nagy értékű árut tartalmaznak az „acéldobozok", azaz elbírják a magasabb szállítási költséget. Más esetekben viszont a hajók ideális kapacitásának 66,6\%-os kihasználtsága csak folyamatos ráfizetés mellett tette volna lehetővé a konténerszállítást. A transzeurópai vízi út legfontosabb (korszakos jelentőségűnek szánt) elemének tervezésekor egyoldalúan magára a csatorna nyomvonalára, zsiliprendszerére és mederparamétereire összpontosult a figyelem, viszont nem voltak eléggé körültekintőek a prognosztizálható szállításgazdasági tényezőkkel kapcsolatosan. Persze ha időben gondolnak a „háromemeletes” konténerszállítási követelményre, akkor sem biztos, hogy az érdekelt vasutakat és közútkezelőket kötelezni lehetett volna hídjaik szerkezetének megemelésére (Bayerischer Landtag 2008).

Ugyancsak nehezíti a Nyugat-Európával összekötő új vízi út használatát Magyarország részéről, hogy nagyon kevés használható önjáró hajó áll rendelkezésre. Az 1990-es évektől elmaradtak a MAHART tervezett vízijármű-beruházásai, és a mai kisebb magáncégek sem képesek beruházni a zsilipekhez méretezett korszerü hajóállományba. (A csatorna alkalmatlan a korábban szovjet kezdeményezésre elterjedt több bárkás tolóhajózásra.)

Ezért az északi-tengeri megakikötőcsaládba (Range) történő csoportos konténerszállításra igazából a vasút a legalkalmasabb. Már az 1990-es évek óta a Sopronból és Budapestről indított irányvonatok képesek a menetidő 2-3 napra csökkentésére. Működtetőiktől függően többször is változott az induló és célállomásuk (Logisztikai Egyeztető Fórum 2008).

Több tenger nélküli kelet-közép európai országgal szemben Magyarország ma alig képes a Duna menti fekvésból adódó előnyét kihasználni a folyamhajózás révén, mely lehetőséget adna a tengeri hajók által látogatott torkolati kikötők (Galac, 
Tulcea, illetve a torkolatközeli Konstanca) elérésére, átrakással a kombinált vízi szállításra. A szlovákiai komáromi és pozsonyi, az ausztriai kremsi kikötőnek a Duna-torkolati, ellenkező irányban a Duna-Majna-Rajna vízi út révén a rotterdami kikötővel is van kapcsolata. (Még Csehország is kihasználja az Elba vízi utat Hamburg elérésére, főként konténerszállító önjáró uszályok közlekedtetésével - Erdősi 2008a.)

Háborús helyzetekben a tranzitországokon áthaladásnak a Duna és a Rajna nemzetközi vízi úton drasztikus korlátjai lehetnek. (A második világháború alatt a semleges Svájc kénytelen volt leállítani a Rajna-hajózást, ahogyan a délszláv háború alatt és a hídroncsok eltávolítása előtt a szerbiai Duna-szakaszon sem volt lehetőség tranzitra.) Ezen túlmenően a békebeli egyéb rossz tapasztalatok vezettek a 2000. évi CMNI (Egyezmény a belvízi árufuvarozási szerződésről) nemzetközi megállapodás létrehozásához, amelyben a Duna Bizottságon, a Duna-Majna-Rajna-csatornával kapcsolatosan ugyancsak kompetens Rajna Bizottságon kívül az ENSZ is szerepet vállalt (CMNI, Deutsche Gesellschaft für Transportrecht é.n.; Európai Parlament é.n.). A felek megegyeztek abban, hogy ezt az egyezményt kell alkalmazni minden olyan belvízi hajózási szerződésre, amely esetben az áru és berakási kikötője két olyan államban van, melyek közül legalább az egyik az egyezményben szereplő szerződő fél - függetlenül a fuvarozást végző hajó, illetve a feladó vagy a címzett nemzeti hovatartozásától (Valkár 2000).

\section{Hamvába dôlt kísérletek a magyar tengerhajózás újjáélesztésére}

A MAHART az 1970-1980-as évektől néhány tengeri hajójával transzatlanti, kelet-ázsiai és afrikai fuvarokat is végzett. Bár a külgazdasági koncepció értelmében a tengeri szállításnál elsőbbséget élvezett a hazai társaság, a feladatok 4/5-ét részben technikai, részben szolgáltatásszerkezeti okok miatt csak külföldi társaságok tudták ellátni (A MAHART története é.n.).

A konténerizáció előrehaladtával e hajók kihasználtsága oly mértékben romlott, hogy döntés született eladásukról. A magyar tengerhajózásnak a 2000. októberi kormányhatározattal szentesített megszüntetéséről megoszlottak a vélemények. A hajózási szakemberek szerint ez nemzetgazdasági szempontból erősen kifogásolható döntés volt, mivel

- a magyar külkereskedelem kiszolgáltatottá vált a külföldi társaságoknak, akik ezzel visszaélve túl drágán hajlandók szállítani,

- értelmetlenné teszi a fiumei kikötőfejlesztéshez nyújtott magyar állami hozzájárulást, amelynek az volt a célja, hogy a magyar hajóknak ne kelljen várakozniuk a kikötőhelyen kívül, jobb müszaki feltételek mellett végezzék a rakodást, így gyorsabban eljusson az áru a feladótól a megrendelőig.

A magyar hajózási szektor akkori álláspontja szerint a magyar gazdaság elemi érdeke a korábbi hibás döntés korrigálása. Ezért a tengereken való ma- 
gyar jelenlét újbóli megteremtése érdekében az eredményesen működő külföldi tengerhajózási társaságok tapasztalatainak, módszereinek átvételére alapozva a mindenkori magyar közlekedési kormányzatnak bátorítani kell a magyar tengerhajózási tevékenység újraindítására irányuló vállalkozói kezdeményezéseket, és ki kell dolgozni a tengerhez való kijutással, a tengeri kikötői és hajózási szolgáltatások igénybevételével, továbbá mindezek fejlesztésével kapcsolatos stratégiai részkérdéseket.

A kormányzat viszont azt a véleményt képviselte, hogy gazdaságunk erős külkereskedelmi irányultsága miatt magyar szempontból a tengerhajózás természetesen fontos közlekedési alágazat, azonban magához a tengerhajózási tevékenység gyakorlásához nem füződik különösebb nemzetgazdasági érdek.

Formálisan ugyan akár a tengerhajózás újraéledése első megnyilvánulásának is elkönyvelhető lenne az a mozzanat, hogy 2002-ben a MAHART állományába került két 4500 tonnás tengeri áruszállító hajó (a Pannon Star és a multifunkcionális, de alapvetően konténerszállításra használható Pannon Sun - http://www.hajoregiszter.hu). Mindkét hajót az orosz államadósság törlesztése fejében adta át az orosz kormány. Egy korábbi kötelezettsége alapján a MAHART-nak a hajókat el kellett volna adnia és a kapott összeg 60\%-át a kincstárba be kellett volna fizetnie. Azonban a kilátásba helyezett váratlanul nagyon alacsony eladási árra tekintettel a MAHART állami hozzájárulással üzemeltetni kezdte a Seatrade Kft.-t, hogy a szolgáltatásokból megfelelő bevételre tegyen szert, ebből fizethesse ki a kincstárnak a tartozását (Gyüre 2001). A MAHART-keretektől teljesen függetlenül 2000-től megkezdte működését egy új magyar tengerhajózási társaság, a Fluvius Hajózási és Szállítmányozási Kft. is. Három, part menti hajózásra épített kisebb hajójával az Északi- és Fekete-tenger közötti vonalakon végzett szolgáltatásokat: évente mintegy 70 ezer tonna árut fuvarozott (Bloomberg 2017).

Magyarország a csatlakozás óta kénytelen volt igazodni az EU egységes tengerhajózási politikája szellemében kialakitott szabályozásokhoz, felügyeleti és ellenőrzési kötelezettségekhez; kötelező tehát a közösségi tengeri jogharmonizáció (Valkár 2000). Az új helyzetben bármely, unión belüli vállalkozás magyar lobogó alá helyezhet tengeri hajókat és annak ellenére, hogy Magyarországnak ténylegesen nincs sem tengeri hajója, sem tengerpartja, elvileg a folyam-tengerjáró hajók is magyar (pl. dunai) kikötőben érkezhetnek az unió területére.

Végső soron tehát amikor a teheráru-logisztikában korszakos technológiaként elterjedt a konténerizáció és egyidejűleg gazdasági szerkezetünk módosulása folytán külkereskedelmünkben már kisebb szerepe volt az ömlesztett tömegáruknak, kormányzati szinten gazdaságtalannak találtatott a konténerszállításra nem alkalmas Duna-tengerjáró, később pedig a mélytengeri hajóink üzemeltetése is. Fokozatosan leépült a MAHART tengerhajózási részlege, és Duna-tengerjáró hajók híján megszűnt az átrakás nélküli közvetlen tengeri szállítás lehetősége is. A külföldi társaságokra való rászorultság erősödése miatt távolsági külkereskedelmünk egyik legfontosabb kérdése lett a legmegfelelóbb tengeri 
kikötő(k) megválasztása immár a költséghatékonyság figyelembevételével is (http://www.hajoregiszter.hu).

\section{Kikötőkiválasztási opciók}

Az Osztrák-Magyar Monarchia idején az Adriai-tenger Magyarországhoz tartozó, kb. 190 km hosszú tengerpartján Fiumének 1873-tól (azaz a Budapesttel összekötő vasút elkészülte után) a tengeri kapuszerep ellátása tekintetében nem volt igazi alternatívája. Az osztrák Trieszt jobbára kiegészítő funkciót látott el (ahová Bécsből már 1857 óta vezetett vasút - Erdősi 2000).

Trianon után a drámai mértékben elsorvadt tengeri külkereskedelem továbbra is kénytelen volt az Isztria környéki (immár Olaszországhoz tartozó) két kikötőt igénybe venni tekintélyes olasz/jugoszláv vasúti tranzit-, kikötőhasználati és egyéb díjak fejében.

Az 1945 és 1989 közötti időszakban a parti országokkal kialakult aktuális politikai viszony meglehetősen ellentmondásosan döntötte el, hogy mely kikötőket részesíti előnyben Magyarország. Amikor 1949 és 1954 között Jugoszlávia ellenségnek számított, csak marginális forgalmat keltett hazánk Fiumében. Trieszt szerepe pedig azért vált jelentéktelenné, mert oda a délszláv állam nyugati szegletén keresztül vezetett a vasút. Az akkori kényszerhelyzetben félre kellett tenni a józan („földrajzi”) gazdaságossági szempontú megfontolást, így néhány évig főként a lengyel kikötőkön keresztül kereskedett Magyarország a tengerentúllal. (Még kereskedelmi flottánk anyakikötője is Gdynia lett - Erdősi 1995.)

A Jugoszláviával való politikai viszony normalizálódása után viszont ismét felértékelődtek az Isztria közeli kikötők. Ugyanakkor az 1970-80-as években megtöbbszöröződött külkereskedelemhez nélkülözhetetlenné váltak olyan viszonylatú interkontinentális járatok, melyeket (kellő gyakorisággal) a nyugateurópai „kapitalista” országok kikötőiből indítottak. Kezdetben Rotterdam volt a meghatározó az északi-tengeri kikötők közül, azonban az NSZK (a Bundesbahn által adott fuvarkedvezményekkel és más állami beavatkozásokkal) képes volt Hamburg, majd Bréma felé terelni nemcsak a transzatlanti, hanem a más irányú távolsági forgalom egy részét is. Mi több, nem csupán a konténerforgalmat, hanem még ömlesztett áru fogadását is felvállalva. (Pl. a Murmanszkból érkező apatitot és az afrikai foszfátot is az Elba-torkolat közeli kikötőóriásban rakták Magyarországra indított vasúti szerelvényekre.) Később a másik jelentős átrakó kikötő Antwerpen lett (János 2008).

A rendszerváltás után jó ideig az északi-tengeri kikötők súlya (az Adriához képest háromszoros távolságuk, az elérhetőségüket lehetővé tevő tranzitvasutak és autópályák zsúfoltsága, a kikötők szolgáltatási kapacitásának csúcsra járatása ellenére) tovább növekedett; részben a rászorultság okán (a délszláv háború egy ideig nehezítette, bizonytalanná tette az adriai kikötők használatát), 
részben a jóval korszerủbb atlanti megakikötők rendkívül széles spektrumú, vonzó viszonylatkínálatának a következtében.

Korunkban a nemzeti jövedelem közel 80\%-át realizáló külkereskedelem túlnyomó része Európán belül szárazföldi közlekedési pályákon áramlik. Ezt erősíti, hogy a megjelenő multinacionális cégek messze többsége az előálított termékeik döntő többségét Európán belül értékesíti (Samsung, Sony, autógyártók - a Suzuki kivételével).

Viszont a domináns importból adódóan ma már a tengeri külkereskedelem túlnyomó része nem a közelebbi beltengereken, hanem az óceánokat átszelö vonalakon összpontosul, egyfelöl az Ázsia (fóként Kína), másfelöl az Észak-Amerika által keltett forgalommal. Az interkontinentális szállitások fó eszközei a transznacionális társaságok (jobbára több tízezer tonnás) hajói (Erdősi 2006b). Az óceánjárók közvetlen járatokkal kivitelezett üzemeltetésére azonban csak a megfelelő mélységü és befogadóképességü, részben pedig a hordképesség-kapacitás megfelelő kihasználtságát biztosító forgalmas kikötők alkalmasak. Magyarország számára földrajzi paradoxon, hogy a logisztikai szempontból leghatékonyabb kikötők (Le Havre, Antwerpen, Rotterdam, Amszterdam, Hamburg) a legtávolabbiak, ezért csak az Ibériai-félsziget megkerülésével (másfélezer km-rel hosszabb vízi út árán) érhetők el (Erdősi 2006a). E Range-kikötők logisztikai értéke nem csupán abban van, hogy belőlük többszörös viszonylatban van lehetőség az átrakás nélküli szállításra, hanem az is óriási előnyük, hogy jóval gyakrabban indulnak a járatok, rövidebb ideig tartózkodnak a konténerek a kikötőben, rövidebb a várakozási idő. Vonzerejük további elemei közé tartozik szolgáltatásaik magas fokú megbízhatósága, a szállítmánnyal és konténerrel való felelős bánásmód, a magas fokú szervezettség (Erdősi 2004).

Földrajzilag formálisan előnyös opciónak kínálkoznak a közelebbi beltengeri (adriai és fekete-tengeri) kikötők, azonban a szürreális (monopolista) árképzés következtében nincs vagy alig van különbség a Kína-Európa viszonylatban a Hamburgban és az észak-adriai kikötőkben lehorgonyzó (azonos társasághoz tartozó) hajók fuvardíja között. Ugyan a szakági közvélemény folyamatosan hangsúlyozza, hogy a Range-kikötők már bedugultak, kapacitásuk már a jelenlegi forgalomhoz sem elég, ennek ellenére a sekély tengeri területek feltöltésével, a kikötőhelyek és a hozzájuk vezető csatornák mélyítésével biztosítják szolgáltatásaik folyamatosságát.

Az árbeli kiegyenlítettség, a magas szintű szolgáltatások, valamint nem utolsósorban a kifejezetten nagy méretű és merülésű hajókkal kivitelezett járatok indítására és fogadására való felkészültségük további olyan vonzerőt biztosítanak a holland/belga és német kikötőóriásoknak, amelyet az adriai kikötők többféle módon igyekeznek ellensúlyozni.

- A hub-and-spoke (forgalom-összevonó és -szétosztó csomópontra alapozó) logisztikai rendszer alkalmazásával felkínált 2-4 nappal rövidebb szállítási idővel. (A Földközi-tenger valamelyik csomóponti kikötőjében kisebb, ú.n. feeder hajókra átrakással hamarabb jut el a konténer az ad- 
riai célkikötőbe, ami a sürgős vagy a szállítási időre érzékeny áruk esetében az átrakási költséget többszörösen felülmúló előnyt jelent.)

- A kikötők bővítésével, műszaki fejlesztésével, hogy a versenyképességhez elegendő nagyságú hajókat tudjon befogadni és kiszolgálni.

- A kikötőt tápláló hinterlandbeli közlekedési pályák kapacitásának bővítésével, hogy a nagy hajók számára is a gazdaságos üzemelés érdekében elegendő tömegü rakomány álljon rendelkezésre (Erdősi 2017b).

A gazdasági szerkezetváltás eredményeként ma már Magyarország számára a kikötókben a konténerterminálok a legfontosabbak. A konténeresáru-dominancia mellett a kikötőválasztáskor az eljutási időnek kitüntetett szerepe lenne. Viszont a szállítás teljes (a szállítmányt küldőtől a címzettig felmerülő fuvar- és egyéb szolgáltatási) költségét a tengeri kereskedelem logisztika-gazdaságtana csak a negyedik helyen szerepelteti (Bray 2015). Következésképpen önmagában az árunak a megrendelőhöz eljuttatási költsége nem meghatározó. A szállíttató hajlandó többet fizetni, ha a szállítmánya kellő időben és ép állapotban megérkezik a vevőjéhez.

Az előbbiekben vázolt követelménycsomag fontosabb elemeinek elemzésekor kiderül, hogy az Adrián az ömlesztettáru- és olajszállító nagy hajók fogadásához ugyan Fiume, Koper és Trieszt egyes részlegeiben mély víz áll rendelkezésre, a konténerterminálok mindhárom kikötőben egyelőre a közepes vagy annál némileg nagyobb (5000-7000 TEU) konténerhajókat tudják befogadni. Azonban még ezeket is csak akkor érdemes rendszeresen közlekedtetni kontinensek közötti viszonylatokban, ha biztosított a megfelelő kikötői forgalom, aminek nem csupán a hazai hinterland kiterjedése és tengeri külkereskedelmének fajlagos intenzitása, hanem a tranzit is a generálója.

A szárazföldi piac területi bővitésének a vasúti és közúti hálózat fejlettsége, teljesítöképessége, valamint a más tengerpartok vonzása szab határokat. A folyamatban levő fejlesztések alapján a legnagyobb konténerterminál-kapacitásra már középtávon is a fiumei kikötőkomplexum tesz szert. Ezzel szemben a hinterlanddal összekötő vasúti kapacitása éppen Fiume (Rijeka) számára a legproblematikusabb, mivel a 19. századi rendkívül extenzív vonalvezetésủ és sok helyen rossz állapotban levő pálya - már az 1990-es évek elején tervezett - rekonstrukciója érdemileg még el sem kezdődött. A kikötői és a vasúti kapacitás közötti diszkrepancia beláthatatlan ideig visszafoghatja Horvátország messze legjelentősebb kikötőjének forgalmát, de különösen a nemzetközi konténertranzitot, mivel a Magyarországgal összekötő autópályán csak a kifejezetten nagy értékủ konténeres áruk szállítása gazdaságos.

Koper viszont képes volt kihasználni a Magyarországgal 2001-ben létrejött, a fiumeinél nagyobb kapacitású közvetlen vasúti összeköttetésből származó előnyét, melyhez még az igényektől alig elmaradó folyamatos kikötői műszaki fejlesztés és hatékony szervezés is társul. A szlovén kikötő ezért meg tudta szerezni Fiume Kárpát-medencei piacának jelentős részét és ezzel a konténerforgalomban nemcsak Fiumét, hanem Triesztet is felülmúlta. 
Mindhárom Isztria közeli kikötő interkontinentális forgalmában még mindig meghatározó a közvetett hub-and-spoke rendszer. (Az ennek kulcselemeit képező csomóponti átrakó - transshipment - kikötők közé tartozik Taranto, Cagliari, Pireusz, Asdód, Port Szaid és Málta, de főként az Európai Közösség kezdeményezésére Calabria partján létesített Gioia Tauro.) Azonban az utóbbi időkben már számos közvetlen (egyelőre még többségükben európai és amerikai, ám egyre nagyobb számban kínai, tajvani társaságok által üzemeltetett) távol-keleti járat is növeli a kikötők forgalmát (Erdősi 2017b).

Nincs kizárva, hogy a jövőben Magyarország számára tovább növekszik az adriai kikötők szerepe az északi-tengeriekkel szemben. Azaz a gazdaságossági számításoknál a „természetes” földrajzi távolság ismét előtérbe kerül a logisztikai és az egyelőre még torzított költségtávolsággal szemben. Következésképpen a globális közlekedési térbe bekapcsolódásunkhoz nagyobb lehetőség nyílik a hagyományos tengeri kapuinkon keresztül.

\section{A légi közlekedés szerepe a globális személyközlekedési kapcsolatainkban}

Amíg a tengeri hajók a globális gazdaságba, a világkereskedelembe való bekapcsolódás, addig a légi járatok elsősorban személyek, alárendelten nagy értékü áruk távoli térségekbe eljuttatásának fő eszközei. A külföldi kikötőkre utalt tengerhajózással szemben előnyt jelent, hogy a leghosszabb légi járatok működtetésére alkalmas nagy repülőgépek indítására és fogadására hazai (fővárosi) repülőtéren kerülhet sor.

\section{MALÉV-évtizedek}

A nemzetközi légi kapcsolatok irányát, viszonylatait, forgalmi intenzitását a korábbi társadalmi rendszerben sokáig a nagypolitika döntötte el, de a késői „Kádár-korszakban” már a szolgáltatások gazdaságossága is erős szempontnak bizonyult. Ennek megfelelően a MALÉV is igyekezett a tényleges igényekhez közelíteni európai hálózatának alakításakor. Azonban a szocialista országok többségének légitársaságaival szemben a magyarnak nem voltak az interkontinentális távolsági közlekedésre alkalmas repülőgépei, ezért Amerikába, Fekete-Afrikába, a Távol-Keletre stb. prágai, bécsi, frankfurti, moszkvai átszállással juthattak el a Magyarországról induló és az ide tartó utasok (Varga 2012). Közvetlenül a rendszerváltás előtt, majd után néhány éven belül a szolgáltatásai iránt az utasok részéről megnyilvánuló erős keresletnövekedés hatására látványosan bővült a MALÉV nemzetközi hálózata (Erdősi 2005a). Az utasállomány összetétele az utazás célja tekintetében az 1950-1960-as évektől alaposan megváltozott. Egykor kormányzati tisztviselők, állami külkeres- 
kedők, nyugati üzletemberek és magáncélból utazó magasabb jövedelmű személyek alkották az utasok messze többségét, de az 1990-es évektől már a (fogyasztói társadalom által keltett) tömeges turizmus generálja a magyarországi nemzetközi légi forgalom túlnyomó részét. Leegyszerüsítve: a turizmus a globális folyamatoknak, a globalizmusnak ugyan csupán a „szoft” alkotója, míg a légi „hivatásforgalom” (a professzionális tevékenyek által generált forgalom) az érdemi („hard”) összetevője, de mégis a szabadidő eltöltésével kapcsolatos nemzetközi mozgások keltik a legnagyobb forgalmat.

Magyarország zászlós légitársasága az 1990-es években a szovjet gyártmányú (gazdaságtalanul üzemeltethető és erősen környezetterhelő) gépállomány nyugati gyártmányokkal való lecserélésével (Erdősi 2008b, 2008c) egy időben kiszélesítette a kétszintű piacterületet:

- a közepes hatósugarú (főként B737) gépekkel szinte teljes körü európai hálózaton szolgáltatott, de ugyanezekkel a gépekkel elérte az észak-afrikai, közel-keleti, törökországi tengerparti tömegturizmus központjait is,

- míg két nagy hatótávolságú B767-es gép beszerzésével lehetővé vált néhány évig észak-amerikai, karibi és távol-keleti közvetlen járatok közlekedtetése (2. táblázat).

A menetrendszerü New York-i és torontói járatok főként az amerikai magyarok hazalátogatását, kisebb mértékben magyarországi utasok kiutazását voltak hivatva szolgálni. Bár 2000-ben 320 ezer utasa volt a MALÉV e két vonalának, a gépek magas bérleti dija e viszonylatokat is gazdaságtalanná tette a nem megfelelő ülőhely-kihasználás miatt (http://www.malev.hu). (Az egykori nemzeti légitársaság csődbe jutásának további okaival e helyen nem foglalkozunk.)

Századunk elején Ferihegy tengerentúli forgalmából csak 30-40\%-kal részesedett a MALÉV (http://www.malev.hu), a többit nyugati légitársaságok keltették (charterjáratokat észak-afrikai légitársaságok is közlekedtettek - MALÉV Timetable 2004).

2. táblázat: A MALÉV járataival közvetlenül elért Európán kívüli repülőterek 2004-ben Non-European airports directly accessible by MALÉV flights in 2004

\begin{tabular}{llllll}
\hline \multicolumn{2}{c}{ Ázsia-Közel-Kelet } & \multicolumn{2}{c}{ Észak-Afrika } & \multicolumn{2}{c}{ Észak-Amerika és Fekete-Afrika } \\
\hline $\begin{array}{l}\text { menetrendszerü } \\
\text { járatokkal }\end{array}$ & $\begin{array}{c}\text { charter- } \\
\text { járatokkal }\end{array}$ & $\begin{array}{c}\text { menetrendszerü } \\
\text { járatokkal }\end{array}$ & $\begin{array}{c}\text { charter- } \\
\text { járatokkal }\end{array}$ & $\begin{array}{c}\text { menetrendszerü } \\
\text { járatokkal }\end{array}$ & $\begin{array}{c}\text { charter- } \\
\text { járatokkal }\end{array}$ \\
\hline Peking* & Sendai & Kairó & Tenerife & New York & Dominika \\
Bejrút & Bangkok & Tenerife & Agadir & Toronto & Nairobi \\
Damaszkusz & Bodrum & Tripoli & Marrakesh & & \\
Tel-Aviv & Dalaman & & Monastir & \\
& Antalya & & Djerba & \\
& Larnaka & & Sharm el Sheik & \\
& Akaba & & Hurghada & \\
\hline Összesen 4 & Összesen 9 & Összesen 3 & Összesen 7 & Összesen 2 & Összesen 2 \\
\hline
\end{tabular}

* Ülőhelymegosztással a Hainan Airlines üzemeltette.

Forrás: Erdősi (2005a). 


\section{A MALÉV utáni időszak}

A MALÉV kiesése 2012-től csak átmenetileg okozott gondokat a magyarországi vonatkozású nemzetközi légi forgalomban, mivel

- rövid időn belül teret nyertek a Liszt Ferenc repülőtéren a maximum közepes távolságokra eljutást lehetővé tevő diszkont-légitársaságok,

- míg a nagy távolságú interkontinentális utazásokhoz a kiépült autópálya-hálózaton rövid időn belül elérhető Bécs-Schwechat nyújtott bő kínálatot,

- továbbá megjelent Budapesten néhány közel- és távol-keleti légitársaság is interkontinentális kínálatával. Ennek köszönhetően a magyar föváros az utasforgalomban megőrizte pozícióját a többi környékbeli fóvárossal szemben (3. táblázat).

Már az 1990-es évektől többször is felbukkant a magyar közlekedéspolitikában az a bátortalan törekvés, hogy Budapest nemzetközi légi közlekedési csomóponttá váljon a Kárpát-medence tágabb térségében (Tóth 2000). Ennek azonban azért nincsen realitása, mert a tőle mindössze (nettó) 20 perces repüléssel elérhető Bécs (Schwechat) már betölti nem csupán intraeurópai, hanem világrészek közötti viszonylatokban is az átszállóhely szerepkört. (Budapest még Délkelet-Európa és Kelet-Európa nyugati régiói számára sem tudná a csomópont, vagy éppen a gateway szerepet betölteni, mivel a már 2016-ban hétszer nagyobb forgalmú Isztambul a legjobb úton van afelé, hogy a nyugat-európai megarepülőterekkel összevethető kapacitású és nagytérségi jelentőségü, több millió transzferutassal rendelkező légikikötővé váljon - Erdősi 2017a).

3. táblázat: Budapest és a szomszédos fővárosok Európán túli légi közlekedési kapcsolatának intenzitása (személyforgalom, 2015)

Air traffic intensity of Budapest and neighbor country capitals with non-European destinations (passenger traffic, 2015)

\begin{tabular}{|c|c|c|c|c|c|c|c|c|c|c|c|c|}
\hline \multirow[t]{2}{*}{ Föváros } & \multicolumn{2}{|c|}{$\begin{array}{l}\text { Mediter- } \\
\text { ráneum }\end{array}$} & \multicolumn{2}{|c|}{$\begin{array}{l}\text { Kaukázus és } \\
\text { Közép-Ázsia }\end{array}$} & \multicolumn{2}{|c|}{ Perzsa-öböl } & \multicolumn{2}{|c|}{$\begin{array}{c}\text { Dél-és } \\
\text { Kelet-Ázsia }\end{array}$} & \multicolumn{2}{|c|}{ Fekete-Afrika } & \multicolumn{2}{|c|}{ Észak-Amerika } \\
\hline & $M$ & $\mathrm{Ch}$ & $M$ & $C h$ & $M$ & $\mathrm{Ch}$ & $M$ & $\mathrm{Ch}$ & $M$ & $\mathrm{Ch}$ & $M$ & $\mathrm{Ch}$ \\
\hline Budapest & 10 & 16 & 2 & - & 3 & - & 1 & 3 & - & 4 & 2 & - \\
\hline Bécs & 33 & 12 & 2 & - & 6 & 1 & 10 & 4 & 1 & - & 7 & 3 \\
\hline Prága & 12 & 23 & 1 & 2 & 3 & 3 & 4 & - & - & 2 & 2 & 4 \\
\hline Belgrád & 9 & 10 & - & - & 4 & - & - & - & - & - & 1 & - \\
\hline Bukarest & 11 & 12 & - & - & 3 & - & - & - & - & - & - & - \\
\hline Zágráb & 2 & 4 & - & - & 1 & 1 & 1 & 1 & - & - & 2 & - \\
\hline Ljubljana & 2 & 1 & - & - & - & - & - & - & - & - & - & - \\
\hline Pozsony & 2 & 12 & - & - & 2 & 1 & - & - & - & - & - & - \\
\hline
\end{tabular}

M- menetrendszerü, Ch - charterjáratokkal elért desztinációk.

Forrás: Az egyes repülőterek honlapjainak adataiból számította a szerző. A számértékek a közreműködö légitársaságok számával súlyozott célrepülőterek számát jelentik. 
Budapest az Ausztriával kiegészített Kelet-Közép-Európában mind a forgalom méretében, mind az egységnyi lakosra jutó utasszámban ugyan Bécs és Prága után a harmadik helyet foglalja el a környező országok fővárosai között, azonban az átszálló utasok arányában messze elmarad az osztrák és a cseh főváros repülőtereitől. (Pedig a háborús események miatt egy ideig a Nyugat-Balkán forgalmából is részesedett.) Mindamellett Bécs elszívó hatása a legkifejezettebben újabban az alig félórás autózással elérhető pozsonyi repülőtéren érvényesül, viszont a távolabbi Budapesten csak lassítani képes a még mindig dinamikus forgalomnövekedést.

Az összehasonlító vizsgálatba bevont kelet-közép-európai fővárosi repülőterek forgalmának földrajzi orientáció szerinti szerkezete (különösen a legnagyobb távolságú légi összeköttetésekben) nem független a repülőterek nagyságától, forgalmi volumenük alakulásától (3. és 4. táblázat), illetve attól, hogy mennyire jelent vonzó piacot az adott fóváros (és országa) az utazási igényeket kiszolgáló, túlnyomóan külföldi légitársaságok számára.

2016-ban a Liszt Ferenc repülőtér teljes (kereskedelmi és egyéb) utasforgalmának mindössze 9,1\%-át tették ki az Európán kívüli területekre kiutazók és az azokról érkezők (KSH 2017 adataiból számítva). Az első három célterület Izrael, Törökország és az Egyesült Arab Emírségek alapvetően a turizmusnak köszönhették előkelő helyezésüket.

A tágabb értelemben vett (a Kanári-szigeteket és Madeirát, másfelől a Vörös-tenger északi részének partvidékét is magába foglaló) Mediterráneum alapvetően tengeri üdülési, turisztikai funkciót tölt be Európa, így Magyaror-

4. táblázat: Budapest és a szomszédos fővárosi repülőterek forgalmának alakulása Air traffic between Budapest and neighbor country capitals

\begin{tabular}{|c|c|c|c|c|c|c|c|c|}
\hline \multirow[t]{3}{*}{$\bar{E} v$} & \multicolumn{2}{|c|}{ Budapest } & \multicolumn{2}{|c|}{ Bécs } & \multicolumn{2}{|c|}{ Prága } & \multicolumn{2}{|c|}{ Belgrád } \\
\hline & utas, & cargo, & utas, & cargo, & utas, & cargo, & utas, & cargo, \\
\hline & $M f_{0}^{\prime \prime}$ & $1000 t$ & $M f_{0}^{\prime \prime}$ & $1000 t$ & $M f_{0}^{\prime \prime}$ & $1000 t$ & $M f_{0}^{\prime \prime}$ & $1000 t$ \\
\hline 2001 & 4,6 & 45 & & & 6,1 & 30 & 1,5 & 6,4 \\
\hline 2005 & & & 15,9 & 180 & 10,8 & 48 & 2,0 & 7,7 \\
\hline 2010 & 8,2 & 83 & 19,7 & 232 & 11,6 & 58 & 2,7 & 7,4 \\
\hline 2015 & 10,3 & 95 & 22,7 & 290 & 12,0 & 51 & 4,8 & 13,1 \\
\hline \multirow[t]{3}{*}{$\bar{E} v$} & \multicolumn{2}{|c|}{ Bukarest } & \multicolumn{2}{|c|}{ Zágráb } & \multicolumn{2}{|c|}{ Ljubljana } & \multicolumn{2}{|c|}{ Pozsony } \\
\hline & utas, & cargo, & utas, & cargo, & utas, & cargo, & utas, & cargo, \\
\hline & $M f_{0}^{\prime \prime}$ & $1000 t$ & $M f_{0}^{\prime \prime}$ & $1000 t$ & $M f_{0}^{\prime \prime}$ & $1000 t$ & $M f_{0}^{\prime \prime}$ & $1000 t$ \\
\hline 1997 & & & & & & & 0,285 & 1,6 \\
\hline 2000 & & & 11,0 & 7 & 1,0 & 12 & 0,283 & 2,8 \\
\hline 2005 & 3,0 & 17 & 1,6 & 13 & 1,2 & 12 & 1,937 & 5,1 \\
\hline 2010 & 4,9 & 71 & 2,1 & 8 & 1,4 & 17 & 1,665 & 17,7 \\
\hline 2015 & 9,3 & 97 & 2,6 & 9 & 1,4 & 19 & 1,560 & 21,1 \\
\hline
\end{tabular}

Forrás: Erdősi (2007b), valamint egyes repülőterek honlapjai és néhány publikáció adatai alapján. 
szág számára is. Ezért a globális gazdasági kapcsolatok értékelésekor kevés figyelmet érdemel. (E viszonylatokban Budapestet hamarosan utoléri Bukarest.)

A globális gazdaságba bekapcsolódás mértékét a távolabbi világrészekkel, nagyrégiókkal való összeköttetések erössége jelzi igazán (Erdősi 2008b). Ha eltekintünk a részben a turizmus által keltett és nagyrészt még a közepes távolsági kategórián belüli kaukázusi célrepülőterektől, a „keleti nyitás” meghirdetése óta Magyarország számára nagy relevanciája igazán a Perzsa-öböl térsége elérhetőségének van. Az ottani, világviszonylatban a legsikeresebbek közé tartozó gazdag arab országok fölényesen versenyképes légitársaságai (Emirates, flydubai, Qatar Airways, Etihad) nem kevés agresszivitással erősen benyomultak az európai piacra, jelen vannak a 3. táblázatban szereplő repülőtereken is (Erdősi 2017c). Budapest azonban az öbölbeli megarepülőterekkel való kapcsolatok intenzitásában nem jeleskedik (Belgrád felülmúlja, Bukarest utolérte), míg a többmilliárd lelket számláló Dél- és KeletÁzsia rendszeres elérését lehetővé tevő menetrendi közlekedési kapcsolatok terén csak Bécstől és Prágától marad el (Peking, Szöul, Bangkok és Phuket repülőtereire szorítkozóan). A magyar fővárosnak ugyan a „dél felé fordulás” külgazdasági irányzata szempontjából nem közömbös, hogy Fekete-Afrika négy célrepülőterével (Mombasa, Viktória Falls, Zanzibár, Zöld-foki-szigetek) is van kapcsolata, igaz, hogy csupán az idényszerủ és korlátozott számú charterjáratok révén. (E helyzettel nem összehasonlítható Bécs, melynek egyetlen, ám menetrendszerü afrikai légi kapcsolata van, az addisz-abebai.) Nehezen elfogadható, hogy Észak-Amerika eléréséhez a forgalmi feltételek a Liszt Ferenc repülőtéren csupán Zágrábbal megegyezők (melyet Torontóval két társaság járatai kötnek össze).

A környező országokban (nem egyszer erős külföldi tőkerészesedéssel) működnek a rendszerváltás előtti néven (valódi vagy bizonyos értelemben) nemzetinek nyilvánított társaságok. $\mathrm{E}$ körülmény nem kedvez a magyar országimázsnak. A MALÉV megszűnése óta nem létezik Magyarországra utaló nevü érdemleges társaság. A Budapesten bejegyzett diszkonttársaság, a Wizz Air az utasforgalom méretében ugyan kiemelkedik a többiek közül, azonban üzletpolitikai megfontolásból kizárólag A320 és A321 gépekből álló flottájával a maximum középtávú szolgáltatásokra szakosodott (https://wizzair.com). (Kelet felé Dubaj a legtávolabbi célállomása.) Az interkontinentális forgalmat hordozó légitársaságok indító és célrepülőtér-választása sok esetben meglehetősen esetleges - számos motiváció által befolyásolt - szubjektív döntés eredménye. A kereslethez képest eloállt túlkínálat miatt a nagy távolsági szolgáltatók keresik a piaci réseket. Szerencsés esetben hosszú évekig működnek a kiválasztott vonalon, de nem szokatlan a piachoz való túl rugalmas alkalmazkodás, azaz a néhány évenkénti desztinációváltás - sok utas bosszúságára.

Budapest erőssége a légiáru-szállítás. E téren még Prágát is megelőzi, részben a globális kereskedelemben mind fontosabb távol-keleti kapcsolatok száma tekintetében, részben pedig az unikális észak-amerikai kapcsolat működtetésével. (Kontraszt: Belgrádnak, Bukarestnek és Pozsonynak nincs egyetlen menetrendi vagy akár csak charter szintű kapcsolata sem a vizsgált világrészekkel.) 
Bécs forgalma (290 ezer tonna 2014-ben - http://www.vienna-airport.com) ugyan kb. háromszorosa a budapestinek (98 ezer tonna), azonban térkapcsolati rendszere szűkebb. 2016-ban 12 társaság végzett rendszeresen légiáru-szállítási szolgáltatást a Liszt Ferenc repülőtéren, melyek az alkalmi fuvarokat végzőkkel együtt 41 célrepülőtérrel létesítettek kapcsolatot. Ezek többsége ugyan európai, azonban az utasszállító gépek rakterében szállított (ún. belly) cargoval együtt számítva a teljes forgalom több mint a felét Ázsia (elsősorban) Kína keltette exportőrként, de vásárlóként is.

\section{És a jövő? (Néhány feltételezés a globális közlekedési kapcsolatok alakulásáról)}

A tengerentúli világrészekkel való külkereskedelem szállítási feladatainak tömegét

- a gazdasági szerkezet és az energiagazdálkodás további korszerűsödése, az agrárágazat exportképessége,

- a külgazdaság-politika és a legnagyobb távoli partnerországok reagálása, továbbá földrészek szerinti orientációja és

- az importáruk lakossági fogyasztása, a hazai ipari termékek importárutartalmának mértéke együttesen határozhatja meg.

Feltételezhető, hogy a magyarországi lakossági importáru-fogyasztásban India, Banglades, Vietnam részaránya Kínával szemben növekszik, de összességében Ázsia jelentősége középtávon nem változik lényegesen. A jelenlegihez képest nagyobb súlyt képviselhet a jövőben a Szahara alatti Afrika (Nigéria, Ghána, Elefántcsontpart stb.) és Latin-Amerika immár nem csupán trópusi élvezeti cikkek és gyümölcsök, hanem egyszerübb háztartási cikkek exportjával is. Az Egyesült Államok esetlegesen kevésbé nyitott politikája azt eredményezheti, hogy a magas technológia és a speciális termékek importja jelentősebb forrásterületévé válhat Izrael és Japán, de akár Dél-Korea is.

Esély van arra, hogy a magyar agrárgazdaság fejlődése lehetővé teszi nem csupán a gabonaexport növelését (részben segélyprogram-keretekben) a klímaváltozás által leginkább sújtott Száhel-övezetbe, hanem minőségi hústermékek és zöldségkonzervek jóval tömegesebb megjelenését is Kelet-Ázsiától a Közel-Keletig (a piacterület népességének vallási összetételéhez igazodva). A személygépkocsi-piac túlnyomóan ugyan még európai fókuszú, de a jövőben az ázsiai piac mellett megjelenhet Afrika is - az olcsóbb (Suzuki) gyártmányok iránti igényével. A gépipari termékek, szerszámgépek, berendezések globális forgalmában nem várható jelentős növekedés, mivel e tekintetben Magyarország továbbra is Európára orientált marad.

Nagy a valószínűsége annak, hogy a külkereskedelmi (és tranzit)áruk konténerizáltsága a jövőben még nagyobb arányokat ölt (elsősorban ázsiai viszonylatokban). 
A kelet-mediterrán és dél-adriai kikötők (pl. Szaloniki, Bar) jelentősége növekedhet az Isztria közeli kikötőkkel szemben, ha Kína valóban kiépíti az áruinvázióját szolgáló, a Kárpát-medencébe tartó nagy teljesítményủ vasúti pályáját. Addig viszont Koper szerepe tovább növekszik a súlyos hinterland-közlekedési gondokkal küszködő Fiuméhez és az Alpok-térségre orientált Trieszthez képest. Ha pedig túllépve a beltengeri opciókon európai dimenziókban gondolkodunk, a gazdaságossági számításoknál ismét előtérbe kerülhet a „természetes” földrajzi távolság a logisztikai és az egyelőre még torzított gazdasági távolsággal szemben. Ebben az esetben a még mindig domináns északi-tengeri kikötők jelentősen veszítenek szerepükből, és nagyobb lehetőség nyílik a globális közlekedési térbe bekapcsolódáshoz a hagyományos közeli tengeri kapukon keresztül.

Sok bizonytalan tényező befolyásolhatja a távoli világrészek felé irányuló légi személyszállítás irányát és méretét.

- A terrorcselekményektől fenyegetett országok köre szélesedik, olyan országokra is kiterjedhet, melyek ma még ettől mentesnek mutatkoznak. Az utasok többségét képező turisták érzékenyen reagálnak a biztonságukat veszélyeztető valamennyi atrocitásra. Feltételezhető, hogy a hazai közönség által keltett turisztikai célú globális légi forgalom még akkor sem növekszik a korábbi tempóban, ha a repülés biztonsága javul, és a potenciális utasok fizetőképessége nem romlik lényegesen. Egyre többen lehetnek azok, akik a szárazföldön elérhető belföldi és közép-európai nyaralóhelyeket, turisztikai centrumokat látogatják.

- Ugyan az olaj világpiaci ára a kínálattúlsúlyos kereskedelemben alacsony, de a jövőben a kerozin magasabb ára (a piaci egyensúly bekövetkezése, majd a környezeti externáliák érvényesítése nyomán) a repülöjegyek árát is drágítani képes mértékben növekedhet. Természetesen nem rövid távú és nem lineáris változásra, hanem hosszú távú és erős amplitúdókkal izgalmassá váló folyamatra gondolunk.

\section{Összefoglalás}

Külpiacbővítés, illetve versenyképesség érdekében a nem gyarmattartó Magyarország sem mondhatott le a világkereskedelembe való bekapcsolódásból eredő haszonról.

A világtengerhez hozzáférés feltételeinek változásához igazodó mindenkori gazdaság-, illetve közlekedéspolitika döntötte el, hogy a kontinensek közötti áru- és személyszállításra berendezkedik-e Magyarország roppant költséges kereskedelmi flotta és tengeri kikötői infrastruktúra létesítésével, avagy idegen szolgáltatókkal végezteti-e el e feladatot.

Ugyan a dualizmus idején a magyar külkereskedelem bő 80\%-a Európán belüli (és jobbára vasúton kivitelezett) volt - Ausztria túlsúlyával -, a magyar 
kormányok a gazdasági függetlenség elősegítése érdekében arra törekedtek, hogy mennél több viszonylatban nemzeti lobogót viselő hajók álljanak rendelkezésre - nem kevés állami támogatás árán. 1913-ban Fiuméből 66 kikötőbe közlekedtek menetrendszerü járatok. A magyar lobogó alatt - még Brazíliába is - közlekedők aránya 26 és 30\% között mozgott (Erdősi 2017b). A Dél- és Kelet-Ázsia, Észak- és Latin-Amerika piacai felé történő nyitásból a kortársak (Büchelen 1896; Tessner 1913) szerint az ország felülértékelhetetlenül sokat profitált.

A két világháború közötti Fiume nélküli Magyarország alaposan megcsappant külkereskedelmével kapcsolatos tengeri szállításra a nagyfokú alkalmazkodás volt jellemző, mind technológiában (a Duna-tengerjáró hajók forgalomba állításával), mind az idegen tengerhajózási társaságok fokozottabb igénybevételével. Az 1945 utáni gyökeres politikai változás ellenére a tengerhajózásban a korábbi modus vivendi az 1960-1970-es évekig tartott kiegészülve néhány mélytengeri hajó üzemeltetésével. A magyar flotta akkor főként a Földközi-tenger déli és keleti partvidékével folytatott tömegáru-kereskedelmet szolgálta - a szovjet blokk által előnyben részesített politikai céloknak alárendelve.

Már a folyami bárkahordozó mélytengeri hajózás is visszavetette a Dunatengerjáró hajózást, de igazából feleslegessé az egész szállítástechnológiát forradalmasító konténerizáció tette. Magyarország nem tudta lecserélni hagyományos hajóparkját konténerhajókra, míg a Felső-Dunán az átgondolatlan víziútfejlesztések tették gazdaságtalanná a konténerszállítást.

A rendszerváltás utáni súlyos visszaeséskor leginkább a tengerentúli piacokat vesztette el a magyar gazdaság, miközben Nyugat-Európa részaránya átmenetileg magasra szökött. Azonban Kelet-Ázsia harmadik globális gazdasági erőközponttá válásával (árudömpingjével) együtt járt az eurázsiai szárazföldi, tengeri és légi kapcsolatok jelentőségének növekedése. Az e viszonylatban megsokszorozódott tengeri és légi szállítási feladatokból Magyarország azonban csak marginális szerepet volt képes vállalni.

A magyarországi újraiparosítás sajátos szerkezete (az összeszerelő ipar erős pozíciója) már új fejezetet nyitott a globális szállítás módjának alakulásában a konténeres áru és a general cargo arányának erős növekedésével. A globális kombinált szállításba bekapcsolódáshoz Magyarország esélyei azonban gyengék. Azon túlmenően, hogy magyar tengerhajózás és interkontinentális légi szolgáltatás már nem létezik, még a kikötőkbe tartó konténervonatok üzemeltetői is külföldi cégek.

\section{Végkövetkeztetésünk}

Magyarország számára mind a külkereskedelem, mind a turizmus terén az interkontinentális/globális viszonylatok súlya növekvőben van, azonban az itt 
felmerülő áru- és személyszállításból (a keményebbé váló versenyfeltételekkel is számolva) a magyar közlekedés/logisztika csak szerény mértékben (kiegészítő, illetve forgalomszervező tevékenységgel) lesz képes részt venni.

\section{Irodalom}

A MAHART története. http://www.mahartpassnave.hu/en/mahart/about-us/history (Letöltés: 2017. január 28.)

Bayerischer Landtag (2008): Schriftliche Anfrage des Abgeordneten Eike Hallitzky vom 10. April 2008. http://www.bayern.landtag.de/www/ElanTextAblage_WP15/Drucksachen/ Schriftliche\%20Anfragen/15_0010975.pdf (Letöltés: 2016. december 28.)

Bloomberg (2017): Fluvius Hajózási és Szállítmányozási Kft. Company Overview. https://www. bloomberg.com/research/stocks/private/snapshot.asp?privcapId=262303305 (Letöltés: 2017. január 9.)

BR online (2008): Rhein-Main-Donau-Kanal. Güterverkehr zwischen Prognosen und Realität. https://www.br.de/nachrichten/rhein-main-donau-kanal-116.html (Letöltés: 2011. június 8.)

Bray, J. (2015): Economics of sea transport and international trade. Institute Chartered Shipbrokers, Smith, London

Büchelen, A. (1896): Die Adriahäfen und ihre Verbindungen mit dem Hinterlande. Stolz, Wien

CMNI, Deutsche Gesellschaft für Transportrecht. www.transportrecht.org/dokumente/CMNI.pdf (Letöltés: 2017. január 10.)

Erdősi F. (1995): Ágazati és regionális kommunikációföldrajz. II. A tengeri közlekedés földrajza. Egyetemi jegyzet, JPTE TTK Általános Társadalomföldrajzi és Urbanisztikai Tanszék, Pécs

Erdősi F. (2000): A közlekedés fejlődésének területpolitikai vonatkozásai és hatása a területekre és településekre Magyarországon 1944-ig. OKTK, MTA Regionális Kutatások Központja, Pécs

Erdősi F. (2004): Európa közlekedése és a regionális fejlődés. Második bővített kiadás. Dialóg Campus Kiadó, Budapest

Erdősi F. (2005a): Magyarország közlekedési és távközlési földrajza. Dialóg Campus, Budapest, Pécs

Erdősi F. (2005b): Tengerre magyar - de hol? Tranzit, 7., 32-34.

Erdősi F. (2005c): A világ távközlési forgalmának főbb térségi jellemzői. Magyar Távközlés, 5-6., 36-46.

Erdősi F. (2006a): A kínai árudömping tengeri szállítási infrastruktúrái. Navigátor, 9., 26-32.

Erdősi F. (2006b): Globalizáció és a világrészek közötti óriás áruszállító eszközök. A Földrajz Tanítása, 5., 9-14.

Erdősi F. (2007a): Van-e jövője a belvízi közlekedésnek Kelet-Európában? A technológiai, gazdasági, környezeti kihívások és a lehetséges válaszok. Tér és Társadalom, 4., 39-56.

Erdősi F. (2007b): Kelet-Európa országainak légi közlekedése. MTA Regionális Kutatások Központja, Pécs

Erdősi F. (2008a): Kelet-Európa országainak vízi közlekedése. MTA Regionális Kutatások Központja, Pécs

Erdősi F. (2008b): Felzárkózás, lépéstartás vagy leszakadás? A légi közlekedés fejlődésének alapvető problémái és területi különbségei Kelet-Európában I. Közlekedéstudományi Szemle, 1., 16-32.

Erdősi F. (2008c): Felzárkózás, lépéstartás vagy leszakadás? A légi közlekedés fejlődésének alapvető problémái és területi különbségei Kelet-Európában II. Közlekedéstudományi Szemle, 2., 33-43.

Erdősi F. (2010a): Közlekedésföldrajz. In: Tóth J. (szerk.): Világföldrajz. Akadémiai Kiadó, 483-512. (Akadémiai Kézikönyvek)

Erdősi F. (2010b): Világtengerek. In: Tóth J. (szerk.): Világföldrajz. Akadémiai Kiadó, Budapest, 1325-1568. (Akadémiai Kézikönyvek)

Erdősi F. (2017a): Szinergiacsászárok vagy szauruszok? A globális légi közlekedés giga-fordítókorongjai a Közel-Keleten. Közlekedéstudományi Szemle, 3., 1-7. http://doi.org/cjmd

Erdősi F. (2017b): Az Isztria melletti kikötők közötti verseny. Kézirat. MTA KRTK RKI Dunántúli Tudományos Osztály, Pécs 
Erdősi F. (2017c): A Közel-Kelet közlekedése. Publikon, Pécs

Európai Parlament (é.n.): Tengeri szállitás: stratégiai megközelités. http://www.europarl.europa.eu/ atyourservice/hu/displayFtu.html?ftuld=FTU_5.6.11.html (Letöltés: 2016. november 18.)

European Commission (2011): White paper. European transport policy for 2010: time to decide. COM(2001) 370 final. Brüsszel

Fáy A. (1995): 100 éves a Mahart. Közlekedéstudományi Szemle, 8., 282-284.

Fiume hajó- és áruforgalma az 1913. évben. Magyar Statisztikai Közlemények, 54. kötet. Magyar Királyi Központi Statisztikai Hivatal. Budapest, 1915

Gyüre J. (szerk.) (2001): Megfeneklett a magyar tengerhajózás. Gazdaság, július 20.

János Á. (2008): A Maersk és a Kárpát-medence kikötői. Kézirat. PTE Közgazdasági Kar, Pécs

KSH (2017): STADAT - 4.6.16. Budapest Liszt Ferenc Nemzetközi Repülőtér forgalma országonként. http://www.ksh.hu/docs/hun/xstadat/xstadat_evkozi/e_odmj001.html (Letöltés: 2017. február 9.)

Logisztikai Egyeztető Fórum (2008): Logisztikai körkép. http://www.scmonitor.hu/ archivum/2008/2008-junius-logisztikai-korkep (Letöltés: 2016. december 11.)

Magyar Statisztikai Évkönyv 1980-2015. évfolyamai. KSH, Budapest

Magyar tengerhajózás 1945 után. http://www.magyarorszagvizen.hu/szemelyhajozas/magyartengerhajozas-1945-utan (Letöltés: 2016. december 12.)

MALÉV Timetable 2004.

Mizik K. (1995): A Duna-tengerhajózási tevékenység múltja, jelene és jövője. Közlekedéstudományi Szemle, 8., 290-293.

Stopford, M. (2013): Maritime economics. Routledge, London, New York

Tessner, M. (1913): Der Außenhandel Österreich-Ungarn von 1867 bis 1913. Köln

Tóth K. (2000): Ferihegy új regionális pozícióra tör. (Új magyar légügyi stratégia.) Napi Gazdaság, április 27.

Valkár I (2000): A vízi közlekedés jogi szabályozásának EU-csatlakozással kapcsolatos kérdései. Közlekedéstudományi Szemle, 9., 340-346.

Varga G. G. (2012): A MALÉV-sztori. XXI. Század Kiadó, Budapest

http://www.hajoregiszter.hu (Letöltés: 2017. január 9.)

http://www.malev.hu (Letöltés: 2017. február 16.)

http://www.vienna-airport.com (Letöltés: 2017. március 9.)

https://wizzair.com (Letöltés: 2017. február 13.) 